Pre-publication version. This article has been published in the Dutch Journal of Applied

linguistics and is under copyright. The publisher should be contacted for permission to re-use the material in any form.

To cite this article:

Mearns, T. and de Graaff, R. (2018) 'Bilingual Education and CLIL in the Netherlands: The paradigm and the pedagogy', Dutch Journal of Applied Linguistics 7:2, pp. 122-128. DOI: https://doi.org/10.1075/dujal.00002.int

\title{
Bilingual Education and CLIL in the Netherlands:
}

\section{The paradigm and the pedagogy}

The Netherlands is often held up an example of a 'success story' in terms of practices and research regarding the teaching and learning of subject content in a second language (de Graaff \& van Wilgenburg, 2015; Pérez-Cañado, 2012). Nearly 30 years after its initial beginnings, bilingual secondary education in the Netherlands continues to thrive and to evolve in fitting with educational demands, as does the research associated with it. This Special Issue includes contributions addressing Content and Language Integrated Learning (CLIL) as a pedagogical approach in the context of bilingual education as a curricular paradigm, both specifically within the Dutch context. The issue contains six research articles from different perspectives, supported by discussions both from an international research standpoint and from the educational field. It is hoped that the publication of this issue will not only indicate a next stage for bilingual education policy and practice, but also give impetus to new areas for research.

It is fitting that the Dutch Journal of Applied Linguistics has chosen to publish this

Special Issue as we approach the 30th anniversary of bilingual education in the Netherlands. This collection aims to represent the growing body of research into the workings and outcomes of bilingual secondary education (TTO - tweetalig onderwijs) and CLIL in the Dutch context by 
including contributions from six distinct perspectives, supported by commentaries from both local and international standpoints. These contributions will be addressed in more detail towards the end of this introductory contribution, but first it is necessary to place the term 'CLIL' within the broader context of Dutch (bilingual) secondary education. A key question in doing so will be, as is so often asked, that of how the term 'CLIL' should be defined (Morton \& Llinares, 2017).

\section{Context of this Special Issue}

\section{Language and Secondary Education in the Netherlands}

Dutch society is relatively multicultural, with nearly 4 million of its 17 million inhabitants coming from a first or second-generation migrant background (Centraal Bureau voor Statistiek, 2018), and approximately 110 different languages being spoken in homes across the country (Algemeen Secretariaat Nederlandse Taalunie, 2017). The official languages in the Netherlands are Dutch and Frisian (spoken in the North of the Netherlands), although English also occupies a prominent position in society, such that the question has been raised as to whether it should be considered more of a second than a foreign language (Edwards, 2014).

Children in the Netherlands generally enter secondary education at around the age of twelve, after eight years of primary school. Secondary education is tracked, meaning that pupils are placed in different routes, each of which is aimed towards a career at a specific academic level. Placement in a particular route is dependent largely on the recommendation of the primary school, which is based on all-round performance and characteristics as well as the results of standardised national tests. Personal preferences of the pupil and parents also play a role. Mainstream education is divided into three main tracks: VWO (pre-university), HAVO (general) and VMBO (pre-vocational). English is a core subject taught to all secondary school pupils, while they are usually offered a choice of other foreign languages. French and German dominate 
the choices offered, although some schools also offer other Modern Foreign Languages, such as Spanish or Mandarin. In spite of the country's multilingual society, home languages do not generally occupy a strong position in mainstream education.

\section{Bilingual Secondary Education and CLIL in the Netherlands}

Bilingual secondary education in the Netherlands began in 1989 as a grassroots movement initiated by parents and teachers (Maljers, 2007). Bilingual secondary education grew gradually at first but experienced a boom in the 2000s, growing from 26 registered schools in 2000 to 115 in 2010 (Koster \& van Putten, 2014). Currently, the Dutch Network of Bilingual Schools boasts 132 registered schools, of which 115 have obtained official accreditation as bilingual secondary schools (Nuffic, 2018). The languages of instruction at these schools are Dutch and English. The majority of bilingual schools teach bilingually only in the pre-university (VWO) stream, although recent years have witnessed the beginnings of a shift in this trend, with increasing numbers of schools offering a bilingual stream at HAVO (general) or VMBO (pre-vocational) levels. As Denman et al. will emphasise in their contribution to this number, this transition away from the 'elitist' (Weenink, 2005) beginnings of the approach has had a promising start. The majority of bilingual streams follow a similar curriculum to pupils in parallel non-bilingual schools, with the exception of the programme for English in the upper years of the pre-university and general tracks, where pupils follow part of the International Baccalaureate (IB) Diploma Programme. A small number of schools chooses to implement alternative programmes in the lower years, for example the IB Middle Years Programme (MYP) or the International Middle Years Curriculum (IMYC).

Quality control. An aspect of Dutch bilingual secondary education that sets it apart from CLIL programmes in other contexts is the Standard for Bilingual Education (European Platform, 
2012). The Standard requires schools to provide at least $50 \%$ of contact time in English in the first three years of bilingual HAVO and VWO (general and pre-university streams), and 30\% in VMBO (pre-vocational stream). The Standard also incorporates further criteria relating to language proficiency, academic results, curriculum content, school organisation and key teacher competences, the latter being described in an appendix to the Standard entitled 'The competency profile for tto teachers'. The two main 'pillars' of bilingual education as enacted through the current Standard are CLIL pedagogy, and supporting development of European \& International Orientation (EIO). Adherence to the Standard is assessed through an initial audit by a panel of experts, followed by periodical accreditation visits to ensure that standards are maintained (de Graaff \& van Wilgenburg, 2015).

CLIL: Curriculum organisation and pedagogical approach? An important question regarding Dutch bilingual education is its relationship with CLIL. In practice, the two terms are often used interchangeably. This lack of clarity can lead to uncertainty among practitioners regarding the expectations of their teaching and what it means to 'do CLIL': is it enough for them just to teach through the medium of English? Or should they employ particular strategies in order to actively support language learning in their content lessons?

Our understanding of the distinction between CLIL and bilingual education reflects that drawn by Morton and Llinares (2017, p. 1) between CLIL as a "type of programme" (an organizational principle) or as a "pedagogical model" (pedagogical principle). In the Netherlands, bilingual education as it has been described above could be considered the organizational principle. CLIL, in this context, is the pedagogical principle in which (an additional) language and content are addressed together in teaching and learning in order to facilitate the learning of both (Coyle, Hood, \& Marsh, 2010, p. 1). As Dutch bilingual education 
nears its 30th anniversary and entry into a new era, as van Wilgenburg and van Rooijen explain in their contribution, it will be interesting to observe whether the relationship between these terms becomes clearer. For the purposes of the current Special Issue, articles have been included that focus on both of Morton \& Llinares' understandings of CLIL. For the sake of clarity, all of the articles in this issue use the term 'bilingual education' to refer to the organizational principle and the term 'CLIL' only to refer to the pedagogical principle.

\section{CLIL \& TTO Research in the Netherlands}

The Netherlands has been described as being home to "some of the most empirically solid studies into [CLIL] to date in Europe" (Pérez-Cañado, 2012, p. 9). This comment reflects the quality rather than the quantity of research, although the latter is steadily increasing, in particular through the PhD projects represented in some of the contributions to this Special Issue.

Much of the research into Dutch bilingual education to date has focused on the questions of linguistic attainment (e.g. Admiraal, Westhoff, \& de Bot, 2006; Denman, Tanner, \& de Graaff, 2013; Schuitemaker-King, 2013; Verspoor \& Edelenbos, 2009; Verspoor, Schuitemaker-King, van Rein, de Bot, \& Edelenbos, 2010), although, as van Kampen et al. will report, some of these studies also focus on CLIL teaching practices. More recently, research has also focused on individual learner features such as extramural English (Verspoor, de Bot, \& van Rein, 2010), socio-economic status (Sieben \& van Ginderen, 2014) and motivation (Mearns \& de Graaff, 2018; Mearns, de Graaff, \& Coyle, 2017). This focus on learner features, in response to calls in the international CLIL research community for more consideration for the inherent differences between CLIL and mainstream learners due to (self-)selection (Pérez-Cañado, 2012), has suggested that - in the more academic tracks of bilingual education - these differences may well exist. 


\section{Dutch CLIL through the eyes of this Issue}

Building on this basis, the current issue attempts to represent current research into CLIL/bilingual education in the Netherlands in its full breadth. It includes six research papers first presented in a symposium at the triannual conference of the Dutch Association for Applied Linguistics (Anéla) in Egmond-aan-Zee in June 2018 (Anéla, 2018). In the first contribution, van Kampen et al. consider the trends revealed by research into CLIL subject pedagogies in the Netherlands and abroad. Oattes et al. and Dale et al., in turn, examine the roles played by subject and language teachers respectively in a bilingual secondary education setting at the preuniversity and general levels, while Denman et al., in their contribution, focus on the effects of bilingual education at the pre-vocational level. The final two papers approach bilingual education from 'outside' perspectives, Stadt et al. focusing on transfer from English to French in L3 learning and Hajer exploring the relationship between CLIL and her 'sister-movement' within Dutch-medium education, Language-Oriented Content Teaching (LOCT). These papers will be followed by a discussion by Rumlich, who will reflect on the position and challenges of Dutch CLIL research as represented in this Special Issue and suggest directions for future development from an international perspective. To close, van Wilgenburg and van Rooijen provide a response from the field, in which they consider the future of bilingual secondary education in the Netherlands, and potential avenues for research in the light of imminent changes. We hope that, through building further on research such as that presented in this collection, as well as exploring new avenues on both local and international levels, the Netherlands can continue to develop as leader in research and practice in CLIL and bilingual education. 


\section{References}

Admiraal, W., Westhoff, G., \& de Bot, K. (2006). Evaluation of bilingual secondary education in the Netherlands: Students' language proficiency in English 1. Educational Research and Evaluation, 12(1), 75-93. doi:10.1080/13803610500392160

Algemeen Secretariaat Nederlandse Taalunie. (2017). Iedereen taalcompetent! Visie op de rol, de positie en de inhoud van het onderwijs Nederlands in de 21ste eeuw. Retrieved from The Hague: http://taalunieversum.org/sites/tuv/files/downloads/Iedereen taalcompetent.pdf

Anéla. (2018). Symposium: Processes and outcomes of content and language integrated learning in the Netherlands. Presented at the Anéla Applied Linguistics Conference 2018, Egmond-aan-Zee.

Centraal Bureau voor Statistiek. (2018, 2 July 2018). Bevolking; leeftijd, migratieachtergrond, geslacht en regio. Retrieved from https://opendata.cbs.nl/statline/\#/CBS/nl/dataset/37713/table

Coyle, D., Hood, P., \& Marsh, D. (2010). CLIL: Content and Language Integrated Learning. Cambridge: Cambridge University Press.

de Graaff, R., \& van Wilgenburg, O. (2015). The Netherlands: Quality control as a driving force in bilingual education. In P. Mehisto \& F. Genesee (Eds.), Building bilingual education systems: Forces, mechanisms and counterweights. Cambridge: Cambridge University Press.

Denman, J., Tanner, R., \& de Graaff, R. (2013). CLIL in junior vocational secondary education: challenges and opportunities for teaching and learning. International Journal of Bilingual Education and Bilingualism, 16(3), 285-300. doi:10.1080/13670050.2013.777386

Edwards, A. (2014). English in the Netherlands Functions, forms and attitudes. (PhD), King's College, University of Cambridge, Cambridge. Retrieved from https://alisonedwardsdotcom.files.wordpress.com/2012/04/phd-thesis edwards.pdf

European Platform. (2012). Standard for Bilingual Education - havo/vwo. In. Haarlem: European Platform.

Koster, A., \& van Putten, L. (2014). Passie voor tweetalig onderwijs: een geschiedenis van 25 jaar succesvol onderwijs vernieuwen. Utrecht: Europees Platform.

Maljers, A. (2007). The Netherlands. In A. Maljers, D. Marsh, \& D. Wolff (Eds.), Windows on CLIL (pp. 130-138). The Hague: European Platform for Dutch Education.

Mearns, T., \& de Graaff, R. (2018). Bucking the trend? Motivational differences between boys and girls who opt in or out of bilingual education. Journal of Immersion and ContentBased Language Education, 6(1), 1-26. doi:doi:10.1075/jicb.17003.mea

Mearns, T., de Graaff, R., \& Coyle, D. (2017). Motivation for or from bilingual education? A comparative study of learner views in the Netherlands.

Morton, T., \& Llinares, A. (2017). Content and Language Integrated Learning (CLIL): Type of programme or pedagogical model? In A. Llinares \& T. Morton (Eds.), Applied Linguistics Perspectives on CLIL (pp. 1-18). Amsterdam: John Benjamins.

Nuffic. (2018, 18-12-2017). Tto-scholen. Retrieved from https://www.nuffic.nl/voortgezetonderwijs/tweetalig-onderwijs/tto-scholen

Pérez-Cañado, M. L. (2012). CLIL research in Europe: past, present, and future. International Journal of Bilingual Education and Bilingualism, 15(3), 315-341. doi:10.1080/13670050.2011.630064 
Schuitemaker-King, J. (2013). Giving corrective feedback in CLIL and EFL classes. Levende Talen Tijdschrift, 14(2), 3-10.

Sieben, I., \& van Ginderen, N. (2014). De keuze voor tweetalig onderwijs. Mens en maatschappij, 89(3), 233-255. doi:10.5117/MEM2014.3.SIEB

Verspoor, M., de Bot, K., \& van Rein, E. M. J. (2010). Binnen- en buitenschools taalcontact en het leren van Engels. Levende Talen Tijdschrift, 11(4), 14-19.

Verspoor, M., \& Edelenbos, P. (2009). Tweetalig onderwijs: beter geschoolde leerlingen in 2024. In R. d. Graaff \& D. Tuin (Eds.), De toekomst van het talenonderwijs: Nodig? Anders? Beter? (pp. 147-163). Utrecht; Enschede: IVLOS, Universiteit Utrecht; NaB-MVT.

Verspoor, M., Schuitemaker-King, J., van Rein, E. M. J., de Bot, K., \& Edelenbos, P. (2010). Tweetalig onderwijs: vormgeving en prestaties. Retrieved from Groningen:

Weenink, D. (2005). Upper middle-class resources of power in the education arena. Dutch elite schools in an age of globalization. In (Vol. Doctoral thesis). Amsterdam: University of Amsterdam. 